\title{
Nano Silver-Iron-Reduced Graphene Oxide Modified Titanium Dioxide Photocatalytic Remediation System for Organic Dye
}

\author{
Danielle Thandi Sass ${ }^{1}\left(\mathbb{D}\right.$, Emile Salomon Massima Mouele ${ }^{2}$ and Natasha Ross $1, * \mathbb{C}$ \\ 1 SensorLab, Department of Chemistry, University of Western Cape, Private Bag X17, Bellville, \\ Cape Town 7535, South Africa \\ 2 Environmental Nano Science Research Group, Department of Chemistry, University of Western Cape, \\ Private Bag X17, Bellville, Cape Town 7535, South Africa \\ * Correspondence: nross@uwc.ac.za
}

Received: 2 July 2019; Accepted: 20 August 2019; Published: 9 September 2019

\begin{abstract}
The organic water contaminant, methyl orange contaminant (M.O), has shown a hazardous increase in our water systems over the past few years due to its increasing demand in industrial processes. The photocatalytic degradation of the commercial dye was studied through the application of modified $\mathrm{TiO}_{2}$ composite catalysts in aqueous solution under artificial irradiation. The improvement of photocatalytic activity is strongly affected by the various functional groups emerging in the organic substances. In this work, the effect of both silver-iron and silver-iron-reduced graphene oxide-modified titanium dioxide towards M.O remediation as a cost-effective photocatalyst was investigated. We confirmed that the novel $\mathrm{AgFe}$ functionalized $\mathrm{TiO}_{2}$ catalyst $\left(\mathrm{AgFe}-\mathrm{TiO}_{2}\right)$ showed more superior remediation activity than the reduced graphene oxide (rGO)-modified $\mathrm{TiO}_{2}$ due to the decreased band gap from $3.02 \mathrm{eV}-2.5 \mathrm{eV}$ with increased photocatalysis. Based on the spectroscopic and microscopic results, the enhanced photocatalytic degradation of M.O dye was induced by its enhanced surface area, electron diffusion, and the reduction of photo-generated electron-hole pairs' recombination.
\end{abstract}

Keywords: photocatalysis; titanium dioxide; nanocomposite; silver-iron; methyl orange contaminant; band gap

\section{Introduction}

The growth in agricultural and industrial activities has brought about the devastating deterioration of our rivers and groundwater quality due to pollution by hazardous textile contaminant effluents [1]. These pollutants include organic industrial dyes, phenol derivatives, and halocarbons [2]. One of the most harmful dyes, in particular, is methyl orange (M.O) azo dye/orange II $\left(\mathrm{C}_{14} \mathrm{H}_{14} \mathrm{~N}_{3} \mathrm{NaO}_{3} \mathrm{~S}\right)$ [3]; even the slightest quantity $(1 \mathrm{ppm})$ can be detrimental to human health [4]. The reductive cleavage of azo linkages is responsible for the formation of amines, which are classified as toxic and carcinogenic [5]. Hence, methyl orange is regarded as a model pollutant, which is the object of strict environmental regulations on discharging industrial effluents [6,7]. According to environmental standards, the direct discharge of M.O in concentrations higher than $5 \mathrm{mg} / \mathrm{L}$, treated or not, could be detrimental to human health and the aquatic environment $[8,9]$. A significant amount of the total world production of these dyes is estimated to be released into waterways without complete decontamination.

Various technologies have been developed for the removal of azo dyes from water and wastewater to reduce their environmental impact [10]. The common technologies include physical methods (membrane filtration processes and sorption techniques), chemical methods (coagulation or flocculation 
and advanced oxidation processes (AOPs)), and biological methods (microbial and enzymatic degradation); each technology having its own merits and demerits [11-13].

Amongst these, AOPs are considered economical and simpler alternatives. These processes are based on the generation of highly-reactive and oxidizing hydroxyl radicals $(\mathrm{OH} \cdot)$ in the presence of an irradiated semiconductor metal oxide photocatalyst for the degradation of toxic pollutants or used as pretreatment to produce biodegradable pollutants [14]. To date, the most used photocatalyst is $\mathrm{TiO}_{2}$ due to its photo-stability, low cost, and biological and chemical inertness [15]. Unfortunately, the wide band gap of $\mathrm{TiO}_{2}(\mathrm{Eg}=3.2 \mathrm{eV})$ [16] results in poor absorption of visible light and rapid recombination of the photo-generated electron-hole pairs. However, by increasing the surface area, i.e., the population of active sites for catalytic reaction, and by reducing the band gap energy [17], visible or UV light photocatalysis becomes possible [18-20]. Concomitantly, $\mathrm{TiO}_{2}$ can be functionalized by incorporation of metal ions [21-25]. It is reported that silver, in particular, can facilitate interfacial electron transfer in the composite by acting as an electron-conduction bridge and is conducive to retarding electron-hole recombination [26,27]. In this regard, modified- $\mathrm{TiO}_{2}$ catalysts have proven favorable for photocatalytic degrading of methyl orange and phenol as compared to bare $\mathrm{TiO}_{2}$ [28]. In this study, we investigated and compared the photocatalytic degradation ability of both reduced graphene oxide and $\mathrm{Ag}-\mathrm{Fe}$ bimetal nanoparticles with $\mathrm{TiO}_{2}$, respectively. Photocatalytic enhancement imparted by the presence of graphene on a photocatalyst has been shown to fluctuate as a result of the model contaminant studied [29]. Both Ag and Fe are considered as suitable substances for photocatalysis due to their low cost and electro catalytic activity [30-33]. A low band gap, visible/UV light absorption, fast electron diffusion, and fast rate for methyl orange degradation are considered the gold standard to evaluate most accurately the photocatalyst quality [34-41]. Available records revealed that no work has been reported on the influence of $\mathrm{AgFe}-$ modified $\mathrm{TiO}_{2}$ functional groups on the photocatalytic degradation of methyl orange, which is the main purpose of this research work.

\section{Materials and Methods}

\subsection{Chemicals}

Methyl orange dye (4-dimethylaminoazobenzene-4'-sulfonic acid sodium salt), conforming to specifications defined by the American Chemical Society (ACS) reagent ( $85 \%$ ), isopropanol (98\%), tetraisopropyl-orthotitanate ( $97 \%)$, ferrous sulfate heptahydrate $(99 \%)$, nitric acid silver (I) salt (>99\%), graphene oxide, and polyethylene glycol were obtained from Sigma Aldrich Co. A 1000-ppm stock solution was prepared by dissolving $1000 \mathrm{mg}$ of it in $1000 \mathrm{~mL}$ of distilled water, and the required solutions were prepared by suitable dilution. All other chemicals were of analytical reagent grade. Deionized water was used for the preparation and dilution of solutions.

\subsection{Synthesis of Single- and Mixed-Phase $\mathrm{TiO}_{2}$ Powders}

$\mathrm{TiO}_{2}$ powders were fabricated by using a 1:3 ratio of titanium isopropoxide and isopropanol with a total volume of $6 \mathrm{~mL}$. The mixture was stirred in a closed glass container for $10 \mathrm{~min}$ at $60^{\circ} \mathrm{C}$. To the stirring mixture, $5 \mathrm{~mL}$ of acetic acid were added and reserved for $15 \mathrm{~min}$, followed by the addition of $12 \mathrm{~mL}$ of isopropanol. The blend was left to mix for $2 \mathrm{~h}$, followed by heating at $100{ }^{\circ} \mathrm{C}$ in air to allow all the solvent to vaporize. The final gel product, $\mathrm{i}-\mathrm{TiO}_{2}$, was obtained after additional annealing in a muffle furnace at $400^{\circ} \mathrm{C}$ for $2 \mathrm{~h}$. The method was repeated using n-propanol as a solvent to procure $\mathrm{n}-\mathrm{TiO}_{2}$ as the resultant product.

\subsection{Synthesis of $\mathrm{AgFe}$ and $\mathrm{TiO}_{2}-\mathrm{AgFe}-\mathrm{rGO}$ Nanocomposite}

The sol-gel procedure was used due to the advantage of low temperature synthesis, the formation of pure and uniform products, and producing functionalized products [42]. For the synthesis of Ag-Fe, $200 \mathrm{~mL}$ of $\mathrm{NaOH}$ were mixed with $100 \mathrm{~mL}$ of methanol solution containing $0.010 \mathrm{M}$ of $\mathrm{FeSO}_{4} \cdot \mathrm{nH}_{2} \mathrm{O}$ and $0.001 \mathrm{~mol} \mathrm{AgNO}_{3}$ at room temperature under a nitrogen atmosphere and stirring for $30 \mathrm{~min}$. 
The produced nanoparticles (Ag-Fe) were collected through vacuum filtration, rinsed, and dried under a vacuum at $50^{\circ} \mathrm{C}$ for $10 \mathrm{~h}$. To prepare the $\mathrm{Ag}$-Fe/rGO nano composite, $1 \mathrm{~g}$ of graphene oxide was dipped into a $25-\mathrm{mL}$ coating solution $(10 \mathrm{~mL}$ of absolute ethanol and $15 \mathrm{~mL}$ of distilled water) containing $0.01 \mathrm{~g}$ polyethylene glycol (PEG) $(20,000)$ and $1.05 \mathrm{~g}$ of $\mathrm{FeSO}_{4} .7 \mathrm{H}_{2} \mathrm{O}$. The mixture was mixed (stirring at $1000 \mathrm{r} / \mathrm{min}$ ) for $30 \mathrm{~min}$ and then sonicated for $1.5 \mathrm{~h}$. Then, $25 \mathrm{~mL}$ of $0.6 \mathrm{~mol} / \mathrm{L}$ of $\mathrm{NaBH}_{4}$ solution were added dropwise at $0{ }^{\circ} \mathrm{C}$ for $2 \mathrm{~h}$ under vigorous stirring. Thereafter, $15 \mathrm{~mL}$ of $2.6 \mathrm{mmol} / \mathrm{L}$ of $\mathrm{AgNO}_{3}$ were added dropwise under stirring. The product was filtrated and dried in an oven at $60{ }^{\circ} \mathrm{C}$ overnight. Finally, the AgFe-rGO product $(0.2 \mathrm{~g})$ was mixed with $1 \mathrm{~g}$ of $\mathrm{TiO}_{2}$ (Degussa) nanopowder and $3 \mathrm{~mL}$ of $\mathrm{NaOH}(5 \mathrm{M})$. This was further sonicated for $2 \mathrm{~h}$. The $\mathrm{TiO}_{2}-\mathrm{AgFe}-\mathrm{rGO}$ was centrifuged, washed, and dried at $50{ }^{\circ} \mathrm{C}$ under a vacuum.

\subsection{Characterization}

The morphologies of the catalysts were probed by a ZEISS ULTRA high-resolution scanning electron microscope (HRSEM). Scanning electron X-rays were also reflected off the sample's surface, which were collected and interpreted through EDAX. All analysis was performed with high-resolution HRSEM for improved atomic-scale material imagery. A Fourier transform infrared spectrometer (FT-IR, JASCO FT/IR-410) was used to probe the structural coordination of the samples in the wavenumber range from $500-3000 \mathrm{~cm}^{-1}$. The electrochemistry was done by using the conventional three-electrode cell, namely the working electrode (glassy carbon electrode), the reference electrode $(\mathrm{Ag} / \mathrm{AgCl})$, and the counter electrode (platinum wire). The setup was a $\mathrm{CH}$ Instrument electrochemical workstation, as well as a $600 \mathrm{E}$ potentiostat (USA). The electrolyte solution was made up of $\mathrm{LiOH}$ and the sample. The experiment was carried out in an argon atmosphere at room temperature. The CV was used to determine the anodic and cathodic peaks and charge transfer diffusion of the synthesized nanomaterials.

\subsection{Photocatalytic Experimental Setup}

The experimental setup used for the photocatalytic removal of M.O at the applied conditions is presented in Figure 1. The system consisted of a Mega-Ray 160-W/240-V MR160 SPL11/14, UV lamp (with a wavelength of $465 \mathrm{~nm}$ ) from Kimix, a thick 5-mm glass tank, which was lined on the inside with aluminum foil, a glass bowl containing M.O solution, which rested on ice blocks for system cooling, and a magnetic stirrer placed in the vessel to ensure the homogeneity of the solution during the photocatalytic treatment process. Beforehand, the absorbance of standard concentrations of (M.O) dye was measured, and the plot of absorbance vs. standard concentrations resulted in a linear trend according to Beer's law: $\mathrm{A}=\varepsilon \cdot \mathrm{C} \cdot l$, where $\mathrm{A}=$ absorbance (no units), $\varepsilon=$ molar absorptivity coefficient (units $=\mathrm{L} / \mathrm{mol} \mathrm{cm}$ ), $\mathrm{C}=$ concentration of absorbing species (units $=\mathrm{mol} / \mathrm{L}$ ). and $l=$ path length (units $=\mathrm{cm}$ ). At the end of each timed photocatalytic experiment, UV-Vis spectroscopy was utilized as an immediate measure of absorbance. The linear calibration was then used to approximate the unknown concentration of (M.O) dye at each sampling time.

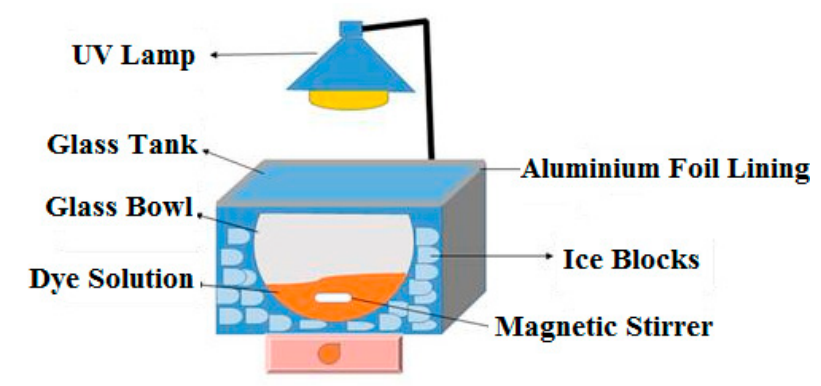

Figure 1. Photocatalytic experimental setup. Solution volume $=500 \mathrm{~mL}$, and irradiation time $=120 \mathrm{~min}$. Mega-Ray 160-W/240-V MR160 SPL11/14, UV lamp. 
Even though various factors may affect the removal of pollutants in water, in the current photocatalytic system, the initial dye concentration and solution $\mathrm{pH}$ were considered, and their impact on M.O degradation percentage was investigated by varying each parameter while other factors were kept constant. Each experiment was performed for $2 \mathrm{~h}$ by sampling every $30 \mathrm{~min}$. The degradation percentages of M.O at the corresponding concentration were calculated using the formula presented in Equation (1).

$$
\text { Degradation } \%=\left[\frac{C_{o-} C_{t}}{C_{o}}\right] \times 100
$$

\section{Results}

\subsection{Characterization of the Catalyst}

\subsubsection{Scanning Electron Microscopy}

From the materials science perspective of $\mathrm{TiO}_{2}$, it is important to consider both the presence of metallic and/or non-metallic dopants and the size and architecture of the catalyst, as these affect its photocatalytic activity [43]. Hence, the initial objective was to find the most suitable and highly reproducible known titanium dioxide nanostructures. Figure 2 illustrates three different forms of $\mathrm{TiO}_{2}$. Image (a) is the $\mathrm{TiO}_{2}$ Degussa nanopowder, which appears as agglomerated particles; roughly spherical in shape and approximately $15-25 \mathrm{~nm}$ in diameter. This was an indication of good dispersion, as it had a large surface area. Image (b) shows the $\mathrm{TiO}_{2}$ nanotubes, having long, tube-like, cross-stacked features with improved mechanical adhesion and size being roughly $1 \mu \mathrm{m}$ in length and $60 \mathrm{~nm}$ in width. This indicates that $\mathrm{TiO}_{2}$ Degussa had a greater surface area and corresponding photoactivity according to the nanoscience research carried out by Schwarz et al. [44]. Image (c) is the synthesized $\mathrm{TiO}_{2}$ nanospheres. The $\mathrm{TiO}_{2}$ nanospheres were agglomerated, which in turn created much larger particles than if there were great separation between each particle. This could be due to the low temperature/pressure synthesis procedure, which produced particles with an average size of 70-90 nm in diameter. Photocatalysis testing was carried to establish the best photocatalyst before further testing was carried out, the result of which concluded that $\mathrm{TiO}_{2}$ (Degussa) was the best for the remediation of methyl orange from the water. Hence, $\mathrm{TiO}_{2}$ (Degussa) was further used to form the AgFe-TiO and $\mathrm{AgFe}-\mathrm{TiO}_{2}$-rGO composite catalysts.
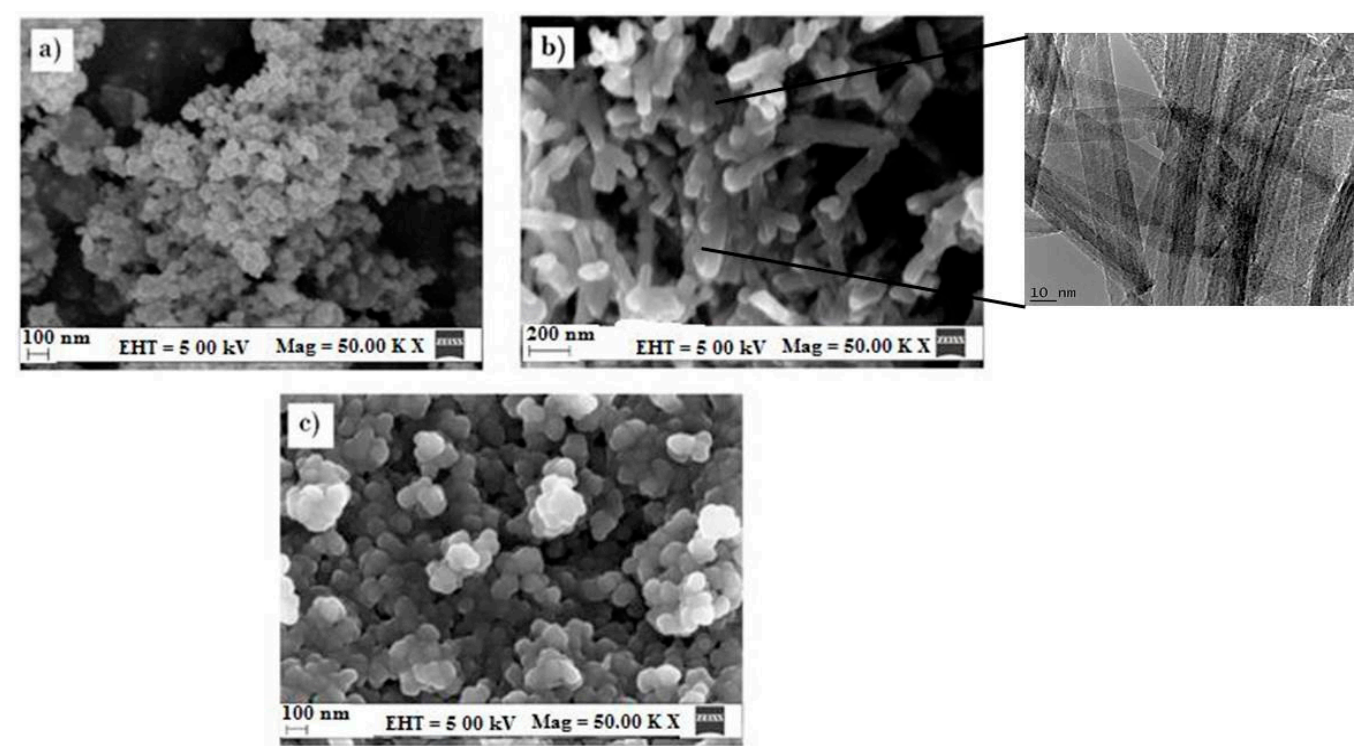

Figure 2. SEM Image of (a) $\mathrm{TiO}_{2}$ Degussa, (b) $\mathrm{TiO}_{2}$ nanotubes, and (c) $\mathrm{TiO}_{2}$ nanospheres at Magnification of $50.00 \mathrm{kX}$. and electron high tension (EHT) of $5.00 \mathrm{kV}$. 
SEM analysis revealed the solid-state nature, as well as the intimate interaction between $\mathrm{TiO}_{2}$ and composite components. These are essential towards promoting photo charge transportation, as well as concentrating the organic substrate around $\mathrm{TiO}_{2}$. Figure 3a shows the morphological structure of the unmodified $\mathrm{TiO}_{2}$ Degussa catalyst at $20.00 \mathrm{kX}$. From the image, it is clear that the particles were agglomerated and roughly spherical in shape. Figure 3 b shows spherically-shaped AgFe- $\mathrm{TiO}_{2}$ with good dispersion and approximately 15-25 nm in diameter. Research by Ranjit and Viswanathan [45] confirmed that the synergy of $\mathrm{TiO}_{2}$ with $\mathrm{Fe}$ (III) enhanced its photocatalytic activity. Figure 3c shows the $\mathrm{rGO}-\mathrm{AgFe}-\mathrm{TiO}_{2}$, where $\mathrm{AgFe}$ and $\mathrm{TiO}_{2}$ were completely infused with the rGO. Although the thicker catalyst may enhance light absorption, it also created a longer electron diffusion distance, which increased transport resistance and decreased photocatalytic activity. It is, therefore, speculated that photocatalysis would be carried out more efficiently with the $\mathrm{AgFe}-\mathrm{TiO}_{2}$ (b) [46].
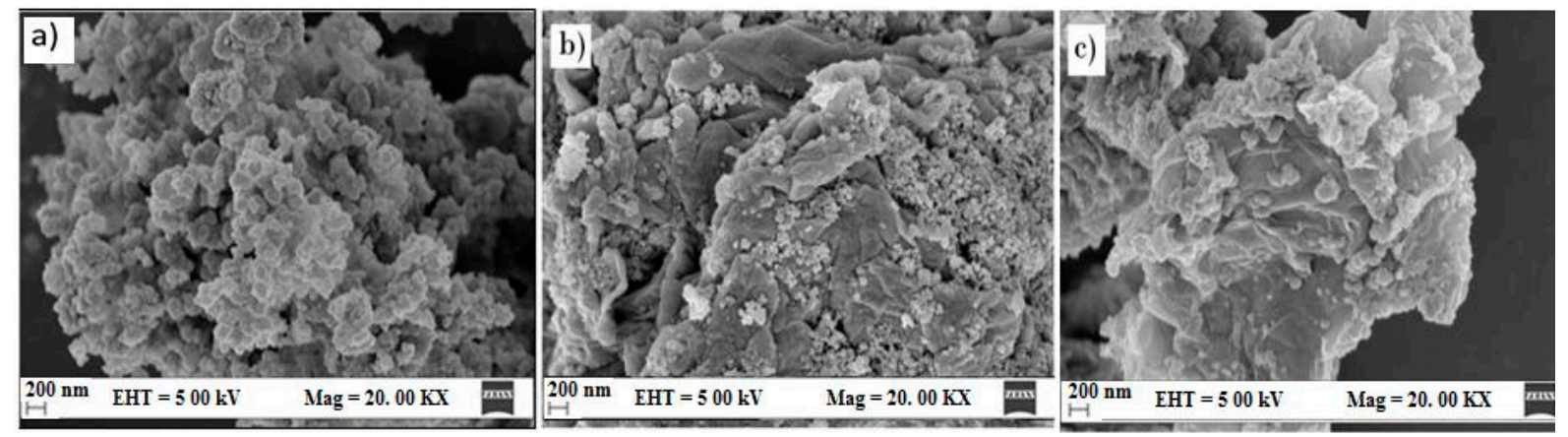

Figure 3. SEM images of unmodified $\mathrm{TiO}_{2}$ Degussa (a), $\mathrm{AgFe}-\mathrm{TiO}_{2}$ (b), and rGO-AgFe-TiO 2 (c) nanocomposites at a magnification of $20.00 \mathrm{KX}$.

\subsubsection{Cyclic Voltammetry}

The fundamental phenomenon observed in semiconductor photocatalyst oxidizing (degrade) organic compounds and reducing metal ions is a promising technique in the treatment of refractory organic pollutants and heavy metals present in wastewater. Electrochemistry was used as a fundamental technique to probe the conduction efficiency and charge transfer resistance of $\mathrm{AgFe}-\mathrm{TiO}_{2}$. Cyclic voltammetry (CV) studies were carried out to investigate the reversibility of the electrode reaction and charge efficiency at room temperature by using the $\mathrm{Ag} / \mathrm{AgCl}$ electrode as a reference and the platinum electrode as a counter. The electronic interactions between the nanocomposites and the catalyst brought about slightly acidic conditions, which increased the rate of electron transfer, thus reducing the rate of electron-hole combination [47]. The separation efficiency between the generated electrons and holes could be explained based on the charge transfer resistance.

$\mathrm{CV}$ was used to probe the reaction mechanism of the system. Figure 4 shows the cyclic voltammograms of (a) $\mathrm{TiO}_{2}$ Degussa/GCE, (b) AgFe-rGO/GCE, (c) $\mathrm{AgFe}-\mathrm{TiO}_{2} / \mathrm{GCE}$, and (d) $\mathrm{AgFe}^{-\mathrm{TiO}_{2}-}$ rGO/GCE. For the $\mathrm{TiO}_{2}$ sample (a), the expected anodic and cathodic redox peaks attributed to the pseudocapacitive nature of the sample were observed. Moreover, the peak current was found to be increased with successive scans. The observed discrepancy can be attributed to the reduction of $\mathrm{Ti}^{4+}$ to $\mathrm{Ti}^{3+}$ as per the reaction described in Equation (2):

$$
\mathrm{TiO}_{2}+\mathrm{e}^{-}+4 \mathrm{H}^{+} \rightarrow \mathrm{Ti}^{3+}+2 \mathrm{H}_{2} \mathrm{O}
$$

In the case of AgFe-rGO (b), the specific capacitance of the system was found to decline with increased scan rate with no distinctive redox peaks. Similar deficiency of electrochemistry is observed in Figure $4 \mathrm{~d}$, and this may be due to the fact that higher scan rates may not afford sufficient time for diffusion at the electrode interface. However, at the $\mathrm{AgFe}^{-\mathrm{TiO}_{2}}$ electrode (c), clear reduction and oxidation peaks resulting from the Faradaic reactions were discernible even at low scan rates, thereby confirming the co-presence of $\mathrm{TiO}_{2}$. The peak currents of both the oxidation and reduction peaks were 
found to increase with a consequent reduction in potential between the peaks. Some reversibility in the redox process was also observed for the $\mathrm{AgFe}-\mathrm{TiO}_{2}$ electrode with the third reduction peak being indicative of the reduction of $\mathrm{Ag}_{2} \mathrm{O}$ to $\mathrm{Ag}$ [48]. It is noteworthy that the pristine $\mathrm{TiO}_{2}$ was composed of both rutile and anatase phases, whereas the modified $\mathrm{TiO}_{2}$ was composed mainly of the rutile phase. In addition, the AgFe-rGO, $\mathrm{AgFe}-\mathrm{TiO}_{2}$, and $\mathrm{AgFe}-\mathrm{TiO}_{2}-\mathrm{rGO}$ samples could have the combined effect of the faradaic capacitance of the $\mathrm{TiO}_{2}$ and the double-layer capacitance of the carbon and AgFe. This facilitated the enhanced conduction pathways with the modified catalysts [49].
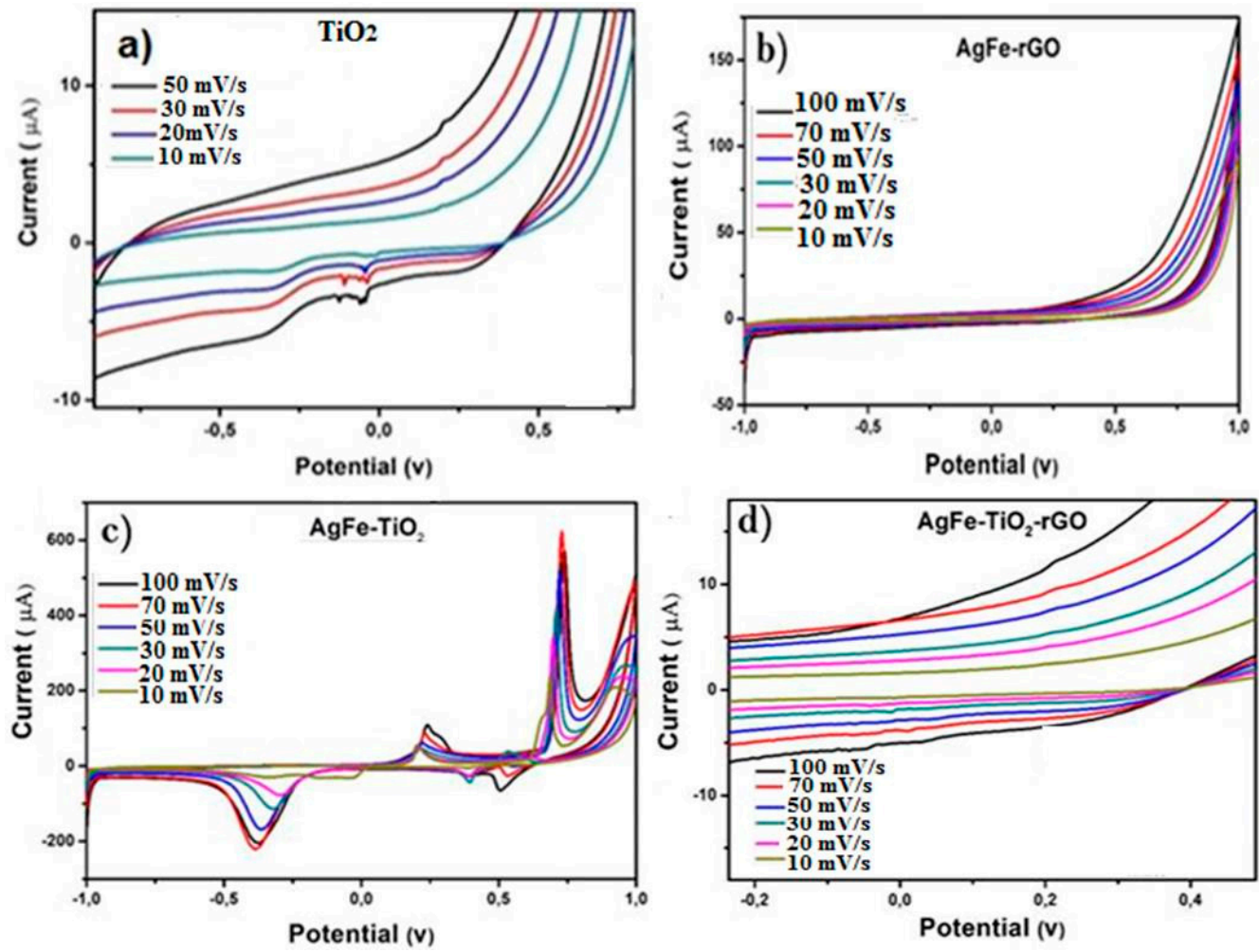

Figure 4. $\mathrm{CV}$ graph of $\mathrm{TiO}_{2}$ Degussa (a), $100 \mathrm{mg}$ of $\mathrm{AgFe}-\mathrm{rGO}(\mathbf{b}), 100 \mathrm{mg}$ of $\mathrm{AgFe}-\mathrm{TiO}_{2}$ (c), and $100 \mathrm{mg}$ of $\mathrm{AgFe}_{-}-\mathrm{TiO}_{2}-\mathrm{rGO}(\mathbf{d})$ with the insert in $5 \mathrm{M} \mathrm{LiOH}$ electrolyte at scan rates from $10-100 \mathrm{mV} / \mathrm{s}$ in $5 \mathrm{M}$ $\mathrm{LiOH}$ electrolyte on glassy carbon electrode (GCE).

The diffusion coefficient (D) in $\mathrm{cm}^{2} / \mathrm{s}$ of $\mathrm{H}+$ ions was calculated by using the Randles-Sevcik Equation (3), where $\mathrm{n}$ is the number of electrons transferred in the redox event, $\mathrm{A}$ is electrode area in $\mathrm{cm}^{2}, \mathrm{C}$ is the concentration in $\mathrm{mol} / \mathrm{cm}^{3}, v$ is the scan rate in $\mathrm{V} / \mathrm{s}$, and jis the peak current density [50]. Compared to the $\mathrm{D}$ for the pure $\mathrm{TiO}_{2}$ electrode, determined to be $1.07 \times 10^{-7}$, the diffusion coefficient for $\mathrm{AgFe}-\mathrm{TiO}_{2}-\mathrm{rGO}$ and $\mathrm{AgFe}^{-\mathrm{TiO}_{2}}$ was $2.44 \times 10^{-5} \mathrm{~cm}^{2} \mathrm{~s}^{-1}$ and $3.39 \times 10^{-5} \mathrm{~cm}^{2} \mathrm{~s}^{-1}$, respectively, which showed an order of magnitude increase with the continuous nanofibers $\left(10^{-6} \mathrm{~cm}^{2} / \mathrm{s}\right)$. The observed enhancement in the diffusion coefficient can be attributed to the lower photocurrent collection time due to the modified morphology. According to research by Rahul Malik et al. (2010), this can be attributed to a decrease in ion mobility due to diffusion in the bulkier sample being much slower [51].

$$
D^{1 / 2}=\frac{j_{p}}{2.72 \times 10^{5} \times n^{3 / 2} \times A \times C_{o} v^{1 / 2}}
$$

Electron diffusion coefficients and recombination lifetimes in the $\mathrm{TiO}_{2}$ films were studied with the size of particles and the film surface area. It was observed that electron recombination lifetimes decreased with the increase of particle size. The presence of rGO sheets is generally believed to improve electron diffusion and charge separation on $\mathrm{TiO}_{2}$ by scavenging photo-generated electrons away from the $\mathrm{TiO}_{2}$ conduction band. However, according to results obtained by Wang et al., it neither 
translates to the generation of more freely loose hydroxyl radicals nor improved adsorption of the organic pollutants on the modified photocatalyst [52]. Equally, in this study, the presence of a higher concentration rGO imparted the limited redox activity as a result of longer diffusion lengths [53]. Here, the $\mathrm{AgFe}-\mathrm{TiO}_{2}$ catalyst showed enhanced electron diffusion due to optimum surface conditions, which was corroborated by its photocatalytic activity.

\subsubsection{UV-Vis Analysis: Determination of the Catalyst Band Gap}

The UV-visible spectra were measured to examine the optical absorption property of the samples, as shown in Figure 5. A sharp absorption peak in the range of $200 \mathrm{~nm}-300 \mathrm{~nm}$, similar to that found by Paul Raj, Samuel in 2013, is shown in Figure 5a and verified the presence of Fe nanoparticles. The band gap for the synthesized Fe nanoparticles was calculated using the onset in the graph and the formula: $E_{\gamma}=h v=\frac{h c}{\lambda}$. It was therefore found that the band gap for Fe nanoparticles was $3.73 \mathrm{eV}$. Figure $5 \mathrm{~b}$ shows the onset and the wavelength of $\mathrm{AgFe}$ with the calculated band gap of $2.5 \mathrm{eV}$. In Figure $5 \mathrm{c}$ the band gap for $\mathrm{TiO}_{2}$ Degussa was calculated to be $2.93 \mathrm{eV}$. This was close to the standard band gap of $\mathrm{TiO}_{2}$ Degussa, which is normally $3.1 \mathrm{eV}$. The lower band gap for the $\mathrm{TiO}_{2}$ Degussa was due to the nanosized particles that were inclined to provide more reactive sites, resulting in better photocatalytic performance [54]. Since the band gap of $\mathrm{AgFe}$ was calculated to be $2.5 \mathrm{eV}$, it could be inferred that it lowered the band gap of the $\mathrm{TiO}_{2}$ and caused a right shift (red shift) of the $\mathrm{TiO}_{2}$ peak. These elements may substitute the oxygen atoms in the $\mathrm{TiO}_{2}$ lattice and decrease its band gap by contributing their p-orbitals $[55,56]$, thereby improving reaction rates for photocatalytic processes.

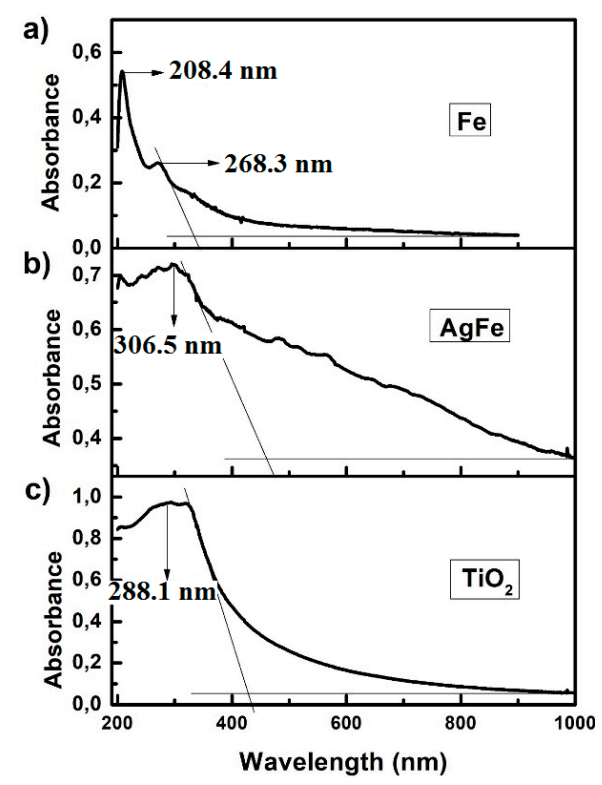

Figure 5. UV-Vis spectra for (a) Fe nanoparticles, (b) AgFe nanoalloy, and (c) $\mathrm{TiO}_{2}$ Degussa.

\subsubsection{XRD Analysis: Determination of the Catalyst Band Gap}

XRD was further used to examine the structures of $\mathrm{AgFe}^{-\mathrm{TiO}_{2}}$ (a), $\mathrm{AgFe}-\mathrm{rGO}(\mathrm{b}), \mathrm{AgFe}-\mathrm{TiO}_{2}-$ rGO (c), and unmodified $\mathrm{TiO}_{2}(\mathrm{~d})$, as shown in Figure 6. In the case of modified- $\mathrm{TiO}_{2}$ nanoparticle films, one peak at $d=3.346^{\circ} \mathrm{A}$ was observed, which was indexed as (101) of the anatase phase in accordance with JCPDS-ICDD Card Number 75-1537. The XRD pattern in Figure 6a clearly shows the main peaks at $(2 \theta) 36.19,44.37$, and 64.56 corresponding to the (111), (200), and (220) planes of Ag, respectively. In addition, the iron oxide particles were confirmed by the peaks at $2 \theta$ at $43.1,51.6$, and 62.6 concerning reflection of the crystal structure of magnetite (400), (440), and (533), respectively. For the AgFe-rGO sample (b), the (002) reflection peak was broad and was centered at around 25 degrees. The d-spacing for $\mathrm{AgFe}-\mathrm{TiO}_{2}$ and $\mathrm{AgFe}-\mathrm{TiO}_{2}-\mathrm{rGO}$ was calculated to be $2.22 \mathrm{~nm}$ and $3.25 \mathrm{~nm}$, respectively. The broadening of the width of the half maximum of the peak in (b) and (c) was due to the reduced graphene oxide 
(rGO). The XRD pattern for unmodified $\mathrm{TiO}_{2}$ films (d) showed no distinct diffraction peaks, indicating its amorphous nature.
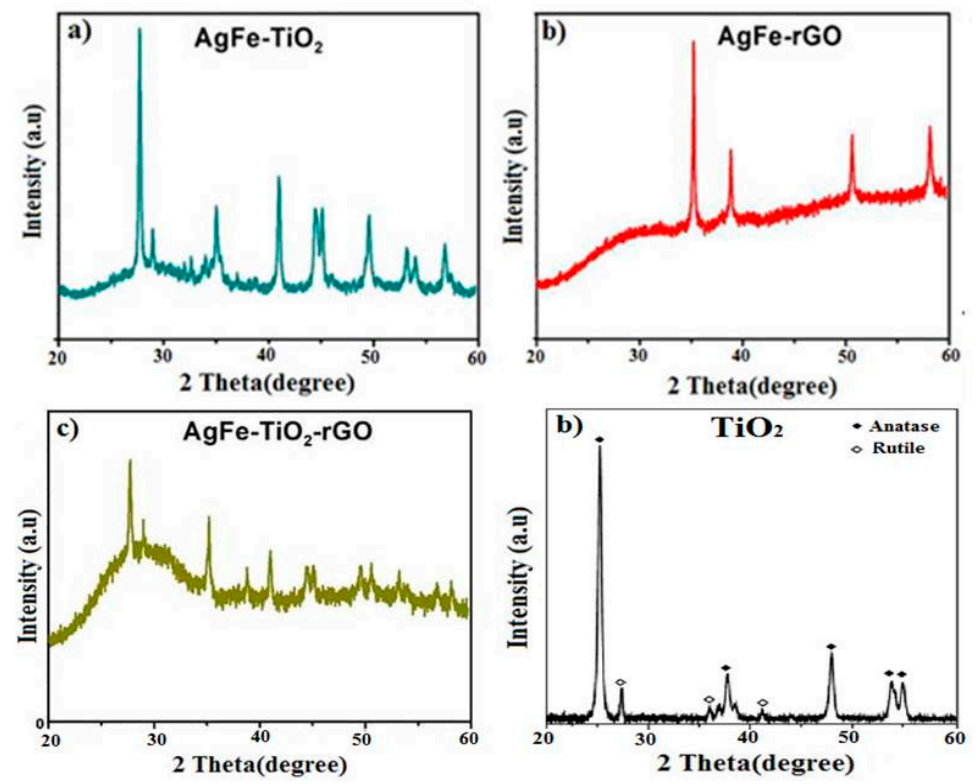

Figure 6. X-ray diffraction (XRD) patterns of (a) $\mathrm{AgFe}^{-\mathrm{TiO}_{2}}$, (b) $\mathrm{AgFe}-\mathrm{rGO}$, (c) $\mathrm{AgFe}-\mathrm{TiO}_{2}-\mathrm{rGO}$, and $(\mathbf{d}) \mathrm{TiO}_{2}$ nanocomposites.

\subsection{Photochemical and Photocatalysis}

\subsubsection{Effect of the Initial Concentration on M.O Degradation Efficiency}

The influence of the initial concentration on the degradation percentage of M.O was assessed by changing its value from $2 \mathrm{mg} / \mathrm{L}$ to $10 \mathrm{mg} / \mathrm{L}$, which encapsulates its permissible limit $(5 \mathrm{mg} / \mathrm{L})$ for municipal and industrial wastewaters, and the results are disclosed in Figure 7. The greatest removal was achieved at $2 \mathrm{mg} / \mathrm{L}$. After $90 \mathrm{~min}$ of UV exposure, 10, 8, and $27 \%$ of M.O removals were achieved with concentrations of 10,6 , and $2 \mathrm{mg} / \mathrm{L}$, respectively. These results suggested that M.O is a sensitive dye whose degradation should carefully be carried out $[57,58]$. Even though $2 \mathrm{mg} / \mathrm{L}$ appeared as the best concentration, in order to meet the sensitivity conditions for the future use of HPLC analysis, $4 \mathrm{mg} / \mathrm{L}$ was chosen as the working concentration of M.O and used for all photocatalysis experiments.

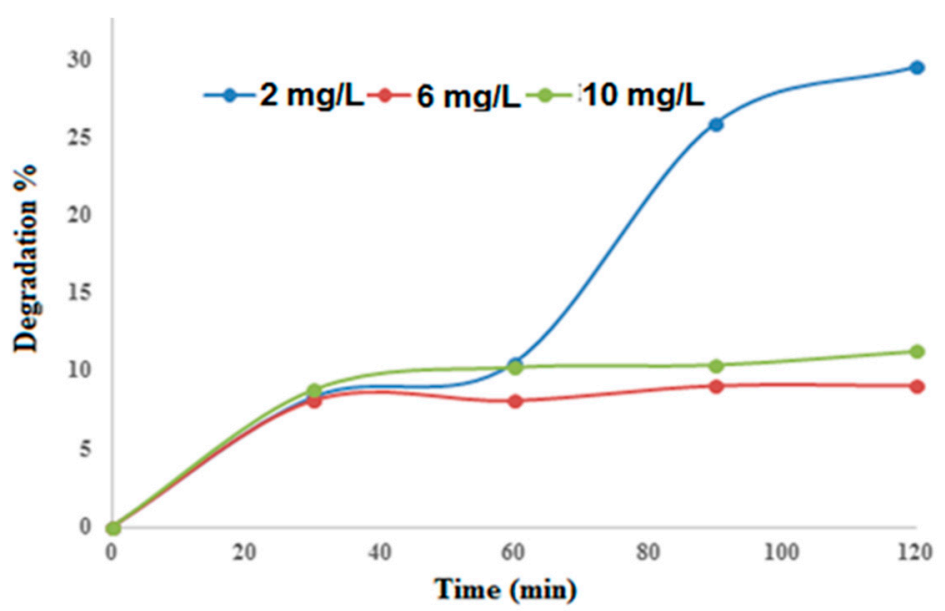

Figure 7. Effect of initial concentration on M.O degradation percentage. Varied parameters: dye concentration of 2,6 , and $10 \mathrm{mg} / \mathrm{L}$, solution volume $500 \mathrm{~mL}$, irradiation time $120 \mathrm{~min}$. 
The bonding characteristics of functional groups in the composites were identified by FTIR, as shown in Figure 8. According to work done by $\mathrm{Ng}$ et al., it is not uncommon that graphene can be detrimental to the photocatalytic activities when the desired properties (e.g., localized high concentration of organic substances adjacent to $\mathrm{TiO}_{2}$ ) are not met [59]. From the spectra of $\operatorname{AgFe}-\mathrm{rGO}(\mathrm{a})$, a band was seen from about $1800 \mathrm{~cm}^{-1}-900 \mathrm{~cm}^{-1}$, caused by the $\mathrm{O}-\mathrm{H}$ bending and stretching, which also appeared in the spectrum (c) for $\mathrm{AgFe}-\mathrm{TiO}_{2}-\mathrm{rGO}$. These confirmed the origin of the band stems from rGO. Spectrum (a) contained a box inset encapsulating the band ranging from $850 \mathrm{~cm}^{-1}-1260 \mathrm{~cm}^{-1}$, which corresponded to Spectrum (c), hence affirming the $\mathrm{C}-\mathrm{C}$ bending and stretching corresponding to rGO. The band at $1624 \mathrm{~cm}^{-1}$ corresponded to the $\mathrm{C}-\mathrm{C}$ bond of $\mathrm{TiO}_{2}-\mathrm{rGO}$ and $\mathrm{TiO}_{2}-\mathrm{Fe}$, which agrees with the work done by Lu et al. (2017) [60]. The peaks at 2927, 1631, and $1383 \mathrm{~cm}^{-1}$ in Spectra (a), (b), and (c) confirmed the presence of silver in the nanocomposite [61].

However, in both Spectra (a) and (c), this band was sharper than that of Spectrum (b), and this was due to rGO enabling a stronger interaction between $\mathrm{AgFe}$ and $\mathrm{TiO}_{2}$ compared to $\mathrm{AgFe}-\mathrm{TiO}_{2}$. $\mathrm{For} \mathrm{TiO}_{2}(\mathrm{~d})$, a broad band at $3360 \mathrm{~cm}^{-1}$ was indicative of the primary $\mathrm{O}-\mathrm{H}$ stretching of the hydroxyl functional group. The band around $1630 \mathrm{~cm}^{-1}(\mathrm{H}-\mathrm{O}-\mathrm{H})$ was due to the incorporation of molecules-ligands into the coordination sphere of surface Ti-atoms, which led to the deformation of the surface $\mathrm{TiO}_{6}$ octahedrons [62]. These groups were the most basic and photoactive ones that accepted defects on the catalyst structure, which agreed with earlier work done by Zhang et al. (2002). A broad absorption band in the low-frequency region $\left(500-800 \mathrm{~cm}^{-1}\right)$ was associated with the Ti-O vibration mode from the structure of Ti-O-Ti bonds [63].
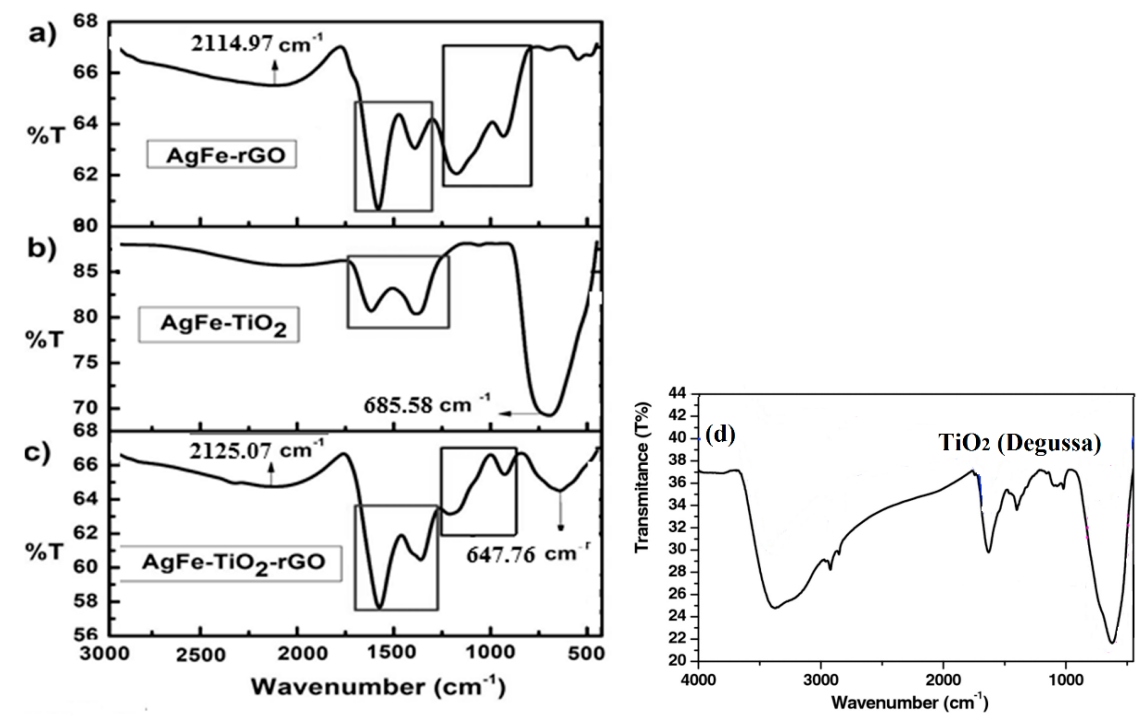

Figure 8. FT-IR spectra for nanocomposites (a) AgFe-rGO, (b) $\mathrm{AgFe}^{-\mathrm{TiO}_{2}}$, (c) $\mathrm{AgFe}-\mathrm{TiO}_{2}-\mathrm{rGO}$, and $(\mathbf{d}) \mathrm{TiO}_{2}$.

\subsubsection{Effect of Solution $\mathrm{pH}$ on the Degradation Percentage of M.O}

Solution $\mathrm{pH}$ is an important parameter for reactions taking place on the surface of a particulate, as is the case of $\mathrm{TiO}_{2}$ photocatalysis. Variations in $\mathrm{pH}$ can influence the adsorption of dye molecules on the $\mathrm{TiO}_{2}$ surfaces. Figure 9 presents the effect of solution $\mathrm{pH}$ on dye percentage removal at the indicated conditions. According to work done by Reza et al. (2017), the degradation percentage of the pollutant may increase with a decrease in solution $\mathrm{pH}$ [64]. The results in Figure 9 indicate that after 90 min of UV irradiation, the highest degradation percentage of methyl orange $98 \%$ was achieved at $\mathrm{pH} 2$ followed by $50 \%, 35 \%, 20 \%$, and $15 \%$ reached at $\mathrm{pH} 5,7,8$, and 9 , respectively. Due to excess anions in the solution, there will be repulsion of the dye by the negatively-charged surfaces of the adsorbents. Therefore, it is clear that the photocatalytic degradation rate of dye solution decreased with the increasing of the initial $\mathrm{pH}$. These findings were in good agreement with work done by Sejie et al. 
(2016) and Niu (2013), who stated that the adsorption process was improved due to the stimulation of the adsorbent surface by the acid in solution at lower $\mathrm{pH}[65,66]$. Concomitantly, in a similar study done by Milenova, K. et al. (2017), this behavior was stated to be influenced by the surface polarity, which contravenes the adsorption capacity [67]. A dye concentration of $4 \mathrm{mg} / \mathrm{L}$ and a solution $\mathrm{pH}$ of two were chosen as the optimum factors for the photochemical oxidation of M.O. These conditions were used to further assess the photocatalytic activity of $\mathrm{TiO}_{2}$ Degussa, $\mathrm{TiO}_{2}$ nanospheres, and $\mathrm{TiO}_{2}$ nanotube catalysts and their effect on the removal of M.O dye, respectively.

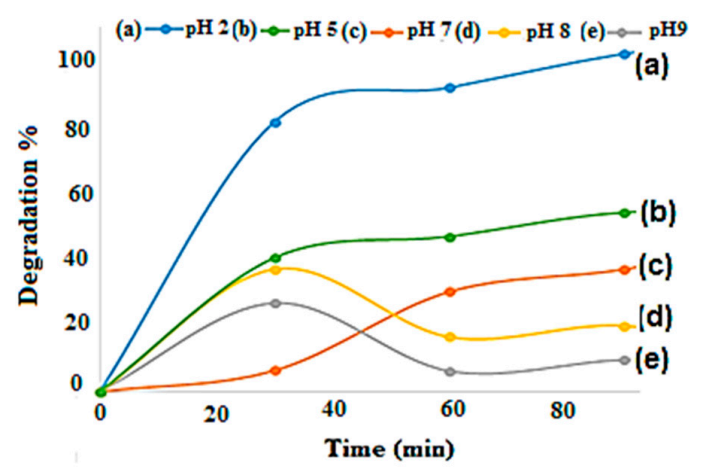

Figure 9. Effect of solution $\mathrm{pH}$ on orange II degradation percentage. Varied parameters: solution $\mathrm{pH} 2,5$, and 9. Fixed parameters: dye concentration $4 \mathrm{mg} / \mathrm{L}$, solution volume $500 \mathrm{~mL}$, and irradiation time $120 \mathrm{~min}$.

\subsubsection{Photocatalytic Applications for the Degradation of Methyl Orange Dye}

The influence of the initial $\mathrm{pH}$ of the solution and the surface area both had an influence on the photocatalysis kinetics; due to the amount of the dye adsorbed on $\mathrm{TiO}_{2}$. From the time-dependent (M.O) degradation percentage graph shown by Figure 10, the highest percentage of degradation of M.O was attained with $\mathrm{TiO}_{2}$ Degussa followed by $\mathrm{TiO}_{2}$ nanospheres and nanotubes, respectively. After 60 min of irradiation, $92.41 \%, 80.91 \%$, and $21.19 \%$ degradations were reached with $\mathrm{TiO}_{2}$ Degussa, $\mathrm{TiO}_{2}$ nanospheres, and $\mathrm{TiO}_{2}$ nanotubes, respectively. $\mathrm{The}_{\mathrm{TiO}}$ Degussa nanomaterial prepared by a sol-gel method had a good crystalline phase and a small crystallite size, which were shown to promote thermal stability and photocatalytic activity. The impact of the amount of $\mathrm{TiO}_{2}$ Degussa on the degradation percentage of dye was also investigated at the applied conditions, and the results are exhibited in Figure 11. The outcomes indicated that dye removal percentage increased with the increase of the amount of catalyst. After 30 min of UV irradiation, total M.O degradation of $99.99 \%$ was achieved with $0.04 \mathrm{~g} \mathrm{TiO}_{2}$ Degussa compared to $94 \%$ and $56 \%$ M.O removals reached with 0.02 and $0.01 \mathrm{~g}$ of $\mathrm{TiO}_{2}$ Degussa, respectively, at the same experimental conditions. These results agreed with what was revealed by previous studies relating the effect of the surface functionalization and morphology of $\mathrm{TiO}_{2}$ on its photocatalytic activity [68-71]

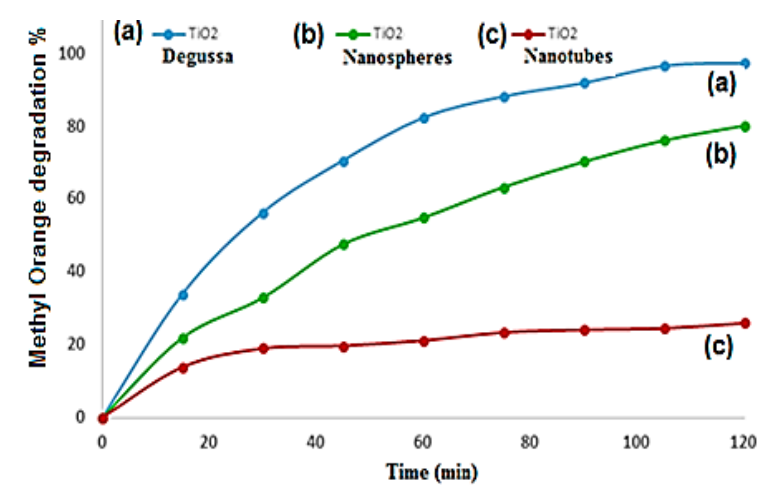

Figure 10. Photocatalytic activity of $\mathrm{TiO}_{2}$ Degussa, $\mathrm{TiO}_{2}$ nanospheres, and $\mathrm{TiO}_{2}$ nanotubes on methyl orange degradation \% at: $\mathrm{pH}$, concentration $4 \mathrm{mg} / \mathrm{L}$, amount of catalyst $0.01 \mathrm{~g}$, and irradiation time $2 \mathrm{~h}$. 
Altogether, the results in Figure 11 show the pollutant concentration and $\mathrm{pH}$; the catalyst dosage is also an important parameter, whose effect should be cautiously assessed during photocatalytic detoxification of water and wastewater pollutants.

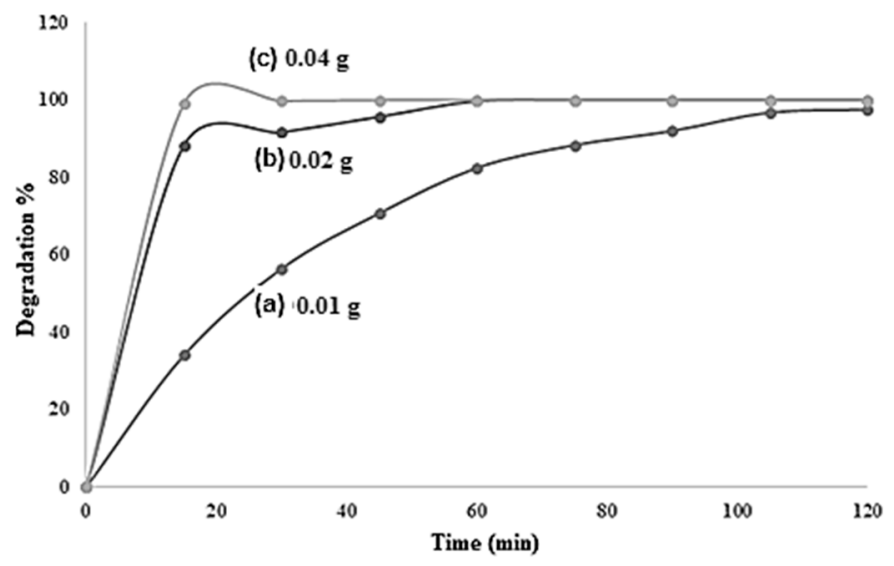

Figure 11. Effect of $\mathrm{TiO}_{2}$ (Degussa) dosage on removal percentage of methyl orange (M.O) dye. Varied parameters: amount of $\mathrm{TiO}_{2}$ Degussa $0.01 \mathrm{~g}, 0.02 \mathrm{~g}$, and $0.04 \mathrm{~g}$.

\subsubsection{Degradation of $\mathrm{M} . \mathrm{O}$ by $\mathrm{TiO}_{2}$ Combined with UV Light: Effect of $\mathrm{TiO}_{2}$ Morphology}

An increase of the catalyst concentration resulted in an increase of the amount of dye adsorbed on the catalyst surface, affecting the catalytic activity of the photocatalyst. Figure 11 presents the effect of photocatalyst dosage on M.O percentage degradation in convenient conditions. Within $2 \mathrm{~h}$ of irradiation, the degradation percentage of M.O increased with an increase in the amount of $\mathrm{TiO}_{2}$ Degussa catalyst. That is, the highest M.O removal was achieved with $0.04 \mathrm{~g} \mathrm{TiO}_{2}$ Degussa, and complete degradation was reached after $60 \mathrm{~min}$ with 0.2 and $0.04 \mathrm{~g} \mathrm{TiO}_{2}$. For instance, after $30 \mathrm{~min}$ of experiment, $56.38 \%$, $91.57 \%$, and $99.67 \%$ M.O removals were achieved with $0.01 \mathrm{~g}, 0.02 \mathrm{~g}$, and $0.04 \mathrm{~g}$, respectively.

\subsubsection{Photocatalytic Degradation of M.O by the Synthesized Catalysts}

A strategy used to inhibit electron-hole pair recombination and previously reported by Mahmoodi, N.M. et al. was to add other electron acceptors to the reaction [72]. Since $\mathrm{TiO}_{2}$ is mostly activated under UV light, it has to be doped or modified to shift its working range in the visible light spectrum [73]. When present at a low concentration, the metal AgFe ions enhanced the dye degradation process. This could be attributed to a suitable trapping of electrons, thereby preventing the recombination of $\mathrm{e}^{-}$and $\mathrm{h}^{+}$pairs. The valence band photogenerated holes were free to react with $\mathrm{OH} \cdot$ adsorbed onto the $\mathrm{TiO}_{2}$ to create hydroxyl radicals $(\mathrm{OH} \cdot)$, and the conduction band electrons (at least a few of them) reacted with electron acceptors such as oxygen, creating oxygen radicals [74]. Therefore, according to the results shown in Figure 12, the degradation of M.O dye was greater in the presence of $\mathrm{AgFe}^{-\mathrm{TiO}} \mathrm{O}_{2}$ as compared to the other photocatalysts and the absence of any catalyst (inset). The results illustrated that within the first 30 min of UV irradiation, faster degradation of M.O was achieved with $\mathrm{AgFe}^{-\mathrm{TiO}_{2}}$ followed by $\mathrm{AgFe}-\mathrm{TiO}_{2}-\mathrm{rGO}$ and $\mathrm{TiO}_{2}$ Degussa. The lower band gap of $\mathrm{AgFe}^{-\mathrm{TiO}_{2}}(2.5 \mathrm{eV})$ shown in Table 1 was expectedly due to the incorporation of $\mathrm{AgFe}$ into the $\mathrm{TiO}_{2}$ frame, which further reduced the electron-hole recombination process, which accelerated the accumulation of electrons in the conduction band (CB) and the proliferation of empty holes on the valence band (VB) [45]. In this regard, charge carriers (electrons and empty holes) possibly promoted the production of free radicals through oxidation $(\mathrm{VB})$ and reduction $(\mathrm{CB})$ processes, which validated the photocatalytic superiority of $\mathrm{AgFe}-\mathrm{TiO}_{2}$ over $\mathrm{AgFe}-\mathrm{TiO}_{2}-\mathrm{rGO}$ and $\mathrm{TiO}_{2}$ as disclosed in Figure 11. Concomitantly, the related pockets that were formed in the nanocomposite of $\mathrm{AgFe}-\mathrm{TiO}_{2}-\mathrm{rGO}$ triggered encapsulation of $\mathrm{M} . \mathrm{O}$ dye molecules instead of remediation [75]. This induced the analogous/misguided observation in the first $30 \mathrm{~min}$. These findings were further corroborated by UV-Vis, and the calculated band gaps are 
shown in Table 1. The tabulated results revealed that remediation in UV or visible light was most satisfactory by the $\mathrm{AgFe}-\mathrm{TiO}_{2}$ catalyst due to its narrow band gap, reduced electron recombination rate, and effective electron diffusion. These findings are in good agreement with an earlier study based on modified- $\mathrm{TiO}_{2}$ catalysts for complete remediation of methyl orange in water under visible light [76].

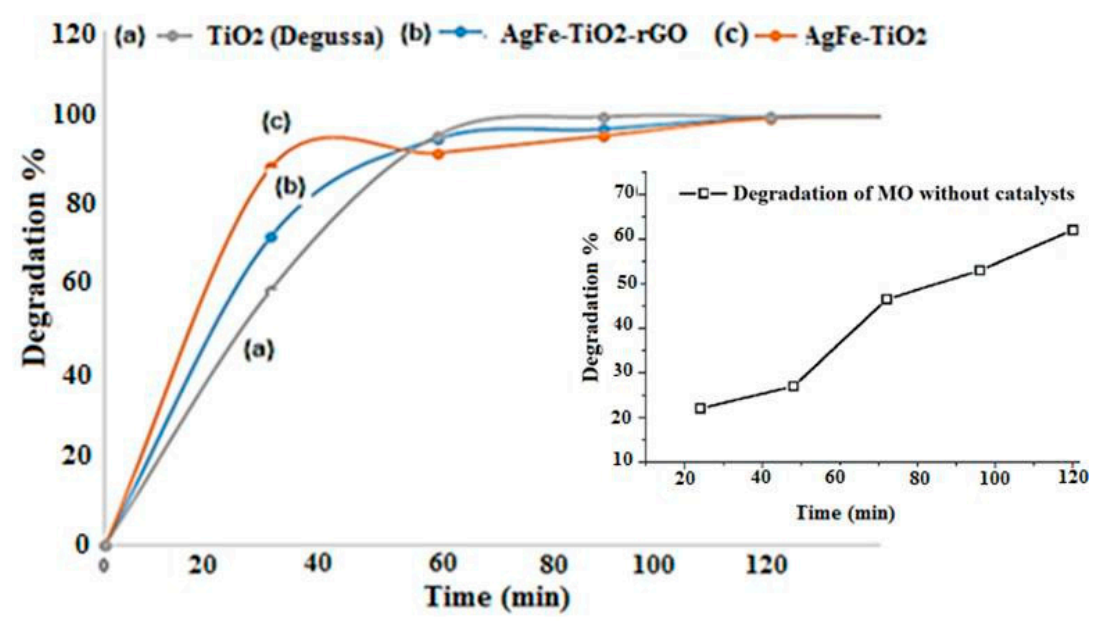

Figure 12. Photocatalytic activity of various catalysts including $\mathrm{TiO}_{2}$ Degussa, $\mathrm{AgFe}-\mathrm{TiO}_{2}-\mathrm{rGO}$, and $\mathrm{AgFe}-\mathrm{TiO}_{2}$ on the degradation percentage of M.O (inset: $\mathrm{MO}$ degradation in the absence of catalyst).

Table 1. Comparison of the three catalysts' remediation potential in accordance with their band gap in the following conditions: solution $\mathrm{pH} 2$, concentration $4 \mathrm{mg} / \mathrm{L}$.

\begin{tabular}{cccc}
\hline Catalyst & Estimated $\Delta \mathrm{E}_{\mathbf{p}}$ & $\mathbf{D}\left(\mathbf{c m}^{\mathbf{2}} \mathbf{s}^{\mathbf{- 1}}\right) \times \mathbf{1 0}^{-\mathbf{5}}$ & Band Gap \\
\hline $\mathrm{TiO}_{2}$ & $0.25 \mathrm{~V}$ & $1.07 \times 10^{-7} \mathrm{~cm}^{2} \mathrm{~s}^{-1}$ & $3.07 \mathrm{eV}$ \\
$\mathrm{AgFe}_{\mathrm{TiO}} \mathbf{2}-\mathrm{rGO}$ & $0.268 \mathrm{~V}$ & $2.44 \times 10^{-5} \mathrm{~cm}^{2} \mathrm{~s}^{-1}$ & $3.02 \mathrm{eV}$ \\
$\mathbf{A g F e}_{\mathbf{T g O O}}$ & $1.06 \mathrm{~V}$ & $3.39 \times 10^{-5} \mathrm{~cm}^{2} \mathrm{~s}^{-1}$ & $2.5 \mathrm{eV}$ \\
\hline
\end{tabular}

\section{Conclusions}

The presence of $\mathrm{AgFe}$ in $\mathrm{TiO}_{2}$ photocatalytic reactions was demonstrated to be beneficial in photocatalytic remediation processes. This was attributed to the improved charge transportation, as well as the pre-adsorption of organic substances adjacent to $\mathrm{TiO}_{2}$. The overall photocatalytic activities were strongly influenced by the chemical structures of the organic substances, and it was evident that graphene could be unfavorable to the photocatalytic activities when the desired properties (e.g., localized high concentration of organic substances adjacent to $\mathrm{TiO}_{2}$ ) are not met. The HRSEM established that $\mathrm{AgFe}-\mathrm{TiO}_{2}$ had a more favorable morphology for photo activity compared to $\mathrm{AgFe}-\mathrm{TiO}_{2}-\mathrm{rGO}$, which allowed for increased adsorption ability, a reduced number of electron-hole re-combinations, and hence, enhanced photocatalytic activity. The corresponding diffusion coefficients for $\mathrm{TiO}_{2}$, $\mathrm{AgFe}-\mathrm{TiO}_{2}-\mathrm{rGO}$, and $\mathrm{AgFe}-\mathrm{TiO}_{2}$ were $1.07 \times 10^{-7} \mathrm{~cm}^{2} \mathrm{~s}^{-1}, 2.44 \times 10^{-5} \mathrm{~cm}^{2} \mathrm{~s}^{-1}$, and $3.39 \times 10^{-5} \mathrm{~cm}^{2}$ $\mathrm{s}^{-1}$, respectively. The $\mathrm{AgFe}-\mathrm{TiO}_{2}$ catalyst, therefore, ensured the adequate detachment of the photo generated carriers, which had excellent charge-transfer ability and in turn performed the best in remediation of the methyl orange dye.

Author Contributions: Formal analysis, D.T.S.; funding acquisition, N.R.; methodology, E.S.M.M.; writing, original draft, N.R.; writing, review and editing, E.S.M.M.

Funding: This research was funded by Center for Afroamerican and African Studies, UM, grant number BGB0326023327 Stem-Africa Seed Grant.

Acknowledgments: The authors thank the South African National Research Foundation (NRF) for the financial support to achieve the completion of this project. 
Conflicts of Interest: The authors declare that there is no conflict of interest in the publication of this manuscript.

\section{References}

1. Von Bormann, T.; Gulati, M. The Food Energy Water Nexus; WWF-SA: Newlands, South Africa, 2014.

2. Ahed, Z.; Zu'bi, A.; Helal, M.H.S.; Park, D.; Campet, G.; Hikmat, S.H. Optimizing photo-mineralization of aqueous methyl orange by nano-ZnO catalyst under simulated natural conditions. J. Environ. Health Sci. Eng. 2015, 13, 46.

3. Maynard, C. Riegel's Handbook of Industrial Chemistry; Kent, J.A., Ed.; Springer: Berlin/Heidelberg, Germany, 1983.

4. Methyl Orange, Material Safety Data Sheet, Statement of Hazardous Nature; sc-206030; Sigma-Aldrich: Saint Louis, MO, USA, 2011.

5. Puvaneswari, N.; Muthukrishnan, J.; Gunasekaran, P. Toxicity assessment and microbial degradation of azo dyes. Indian J. Exp. Biol. 2006, 44, 618-626. [PubMed]

6. Shih, Y.H.; Tso, C.P.; Tung, L.Y. Rapid degradation of methyl orange with nanoscale zerovalent iron particles. Nanotechnology 2010, 7, 16-17.

7. Eljiedi, A.; Azlan, K. Removal of methyl orange and methylene blue dyes from aqueous solution using lala clam (Orbicularia orbiculata) shell. Aip Conf. Proc. 2017, 1, 1847.

8. Tang, C.W. Study of photocatalytic degradation of Methyl Orange on different morphologies of ZnO catalysts. Mod. Res. Catal. 2013, 2, 19-24. [CrossRef]

9. Dina, A.; Scholz, Y.M. Treatment of synthetic textile wastewater containing dye mixtures with microcosms. Env. Sci. Poll. Res. Int. 2018, 25, 1980-1997.

10. Asgher, M.; Kausar, S.; Bhatti, H.N.; Shah, S.A.H.; Ali, M. Optimization of medium for decolorization of solar golden yellow R direct textile dye by Schizophyllum commune IBL-06. Int. Biodeterior. Biodegrad. 2008, 61, 189-193. [CrossRef]

11. Borchert, M.; Judy, A.L. Decolorization of reactive dyes by the white rot fungus Trametesversicolor in sequencing batch reactors. Biotechnol. Bioeng. 2001, 75, 313-321. [CrossRef] [PubMed]

12. Tahir, S.; Rauf, N. Removal of a cationic dye from aqueous solutions by adsorption onto be ntonite clay. Chemosphere 2006, 63, 1842-1848. [CrossRef] [PubMed]

13. Camarero, S.; Ibarra, D.; Martinez, M.J.; Martinez, A.T. Lignin derived-compounds as efficient laccase mediators for decolorization of different types of recalcitrant dyes. Appl. Environ. Microbiol. 2005, 71, 1775-1784. [CrossRef] [PubMed]

14. Wang, J.; Xu, L. Advanced Oxidation Processes for Wastewater Treatment: Formation of Hydroxyl Radical and Application. Crit. Rev.Env. Sci.Tech. 2012, 42, 251-325. [CrossRef]

15. Awuah, E.; Nyarko, K.B.; Owusu, P.A.; Osei-Bonsu, K. Small town water quality. Desalination 2009, 248, 453-459. [CrossRef]

16. Chong, M.N.; Jin, B.; Chow, C.W.; Saint, C. Recent developments in photocatalytic water treatment technology: A review. Water Res. 2010, 44, 2997-3027. [CrossRef] [PubMed]

17. Gaya, U.I.; Abdullah, A.H. Heterogeneous Photocatalytic Degradation of Organic Contaminants over Titanium Dioxide: A Review of Fundamentals, Progress and Problems. J. Photochem. Photobiol. A Chem. 2008, 9, 1-12. [CrossRef]

18. Zhu, K.; Neale, N.R.; Miedaner, A.; Frank, A. Enhanced Charge-Collection Efficiencies and Light Scattering in Dye-Sensitized Solar Cells Using Oriented $\mathrm{TiO}_{2}$ Nanotubes Arrays. J. Nano Lett. 2007, 7, 69-74. [CrossRef]

19. Beranek, R.; Tsuchiya, H.; Sugishima, T.; Macak, J.M.; Taveira, L.; Fujimoto, S.; Kisch, H.; Schmuki, P. Enhancement and limits of the photoelectrochemical response from anodic $\mathrm{TiO}_{2}$ nanotubes. Appl. Phys. Lett. 2005, 87, 243114. [CrossRef]

20. Roy, P.; Berger, S.; Schmuki, P. $\mathrm{TiO}_{2}$ nanotubes: Synthesis and applications. Angew. Chem. Int. 2011, 50, 2904-2939. [CrossRef]

21. Lazar, M.A.; Varghese, S.; Nair, S.S. Photocatalytic Water Treatment by Titanium Dioxide: Recent Updates. Catalysts 2004, 2, 572-601. [CrossRef]

22. Takeuchi, M.; Yamashita, H.; Matsuoka, M.; Anpo, M.; Hirao, T.; Itoh, N.; Iwamoto, N. Photocatalytic decomposition of $\mathrm{NO}$ under visible light irradiation on the $\mathrm{Cr}$-ion-implanted $\mathrm{TiO}_{2}$ thin film photocatalyst. Catal. Lett. 2000, 67, 135-137. [CrossRef] 
23. Linsebigler, A.L.; Lu, G.; Yates, J.T., Jr. Photocatalysis on $\mathrm{TiO}_{2}$ Surfaces: Principles, Mechanisms, and Selected Results. Chem. Rev. 1995, 95, 735-758. [CrossRef]

24. Pável, C.; Hernández, D.C.; Saúl, R.M.; Facundo, R. An Easy and Efficient Method to Functionalize Titanium Dioxide Nanoparticles with Maleic Anhydride. Soft Nanosci. Letters. 2014, 4, 53-62.

25. Li, W.; Shah, S.I.; Huang, C.P.; Jung, O.; Ni, C. Metallorganic chemical vapor deposition and characterization of $\mathrm{TiO}_{2}$ nanoparticles. Mater. Sci. Eng. B 2002, 96, 247-253. [CrossRef]

26. Fernndez-Garca, M.; Martnez-Arias, A.; Hanson, J.C.; Rodriguez, J.A. Nanostructured oxides in chemistry: Characterization and properties. Chem. Rev. 2014, 104, 4063-4104. [CrossRef] [PubMed]

27. Ai, B.; Duan, X.; Sun, H.; Qiu, X.; Wang, S. Metal-free graphene-carbon nitride hybrids for photodegradation of organic pollutants in water. Catal. Today 2015, 258, 668-675. [CrossRef]

28. Liu, J.; Huang, J.H.; Zhou, H.; Antonietti, M. Uniform graphitic carbon nitride nanorod for efficient photocatalytic hydrogen evolution and sustained photoenzymatic catalysis. ACS Appl. Mater. Interfaces 2014, 6, 8434-8440.

29. Hui, L.T.; Frans, D.; Mandalena, H.; Roong, J.W.; Rose, A.; Hau, Y.N.G. Reduced graphene oxide is not a universal promoter for photocatalytic activities of $\mathrm{TiO}_{2}$. J. Mater. 2017, 3, 51-57.

30. Wang, X.; Maeda, K.; Chen, X.; Takanabe, K.; Domen, K.; Hou, Y.; Fu, X.; Antonietti, M. Polymer Semiconductors for Artificial Photosynthesis: Hydrogen Evolution by Mesoporous Graphitic Carbon Nitride with Visible Light. J. Am. Chem. Soc. 2009, 131, 1680-1681. [CrossRef] [PubMed]

31. Yan, $\mathrm{H}$; Yang, $\mathrm{H}$. $\mathrm{TiO}_{2}-\mathrm{g}-\mathrm{C}_{3} \mathrm{~N}_{4}$ composite materials for photocatalytic $\mathrm{H}_{2}$ evolution under visible light irradiation. J. Alloy. Compd. 2011, 509, L26-L29. [CrossRef]

32. Priti, M.; Sulagna, P.; Kulamani, P. An overview of recent progress on noble metal modified magnetic $\mathrm{Fe}_{3} \mathrm{O}_{4}$ for photocatalytic pollutant degradation and $\mathrm{H}_{2}$ evolution. Catal. Sci. Technol. 2019, 9, 916-941.

33. Zheng, Z.K.; Huang, B.B.; Qin, X.Y.; Zhang, X.Y.; Dai, Y.; Whangbo, M.H. Facile in situ synthesis of visible-light

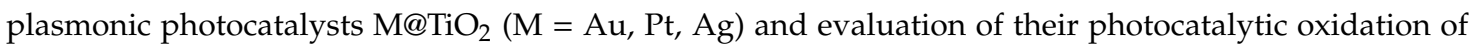
benzene to phenol. J. Mater. Chem. 2011, 21, 9079-9087. [CrossRef]

34. Liang, W.J.; Li, J.; Jin, Y.Q. Photo-catalytic degradation of gaseous formaldehyde by $\mathrm{TiO}_{2} / \mathrm{UV}, \mathrm{Ag} / \mathrm{TiO} 2 / \mathrm{UV}$ and $\mathrm{Ce} / \mathrm{TiO}_{2} / \mathrm{UV}$. Build. Environ. 2012, 51, 345-350. [CrossRef]

35. Sondra, A.; Cristian, P.; Ludovic, L. New one-pot synthesis of Au and Ag nanoparticles using green rust reactive particle as a micro-reactor. Nanoscale Res. Lett. 2013, 8, 95.

36. Yanfeng, C.; Weixin, H.; Donglin, H.; Yue, H. Construction of Heterostructured g- $\mathrm{C}_{3} \mathrm{~N}_{4} / \mathrm{Ag} / \mathrm{TiO}{ }_{2}$ Microspheres with Enhanced Photocatalysis Performance under Visible-Light Irradiation. Acs Appl. Mater. Interface 2014, 6, 14405-14414.

37. Lai, Y.K.; Zhuang, H.F.; Xie, K.P.; Gong, D.G.; Tang, Y.X.; Sun, C.J.; Chen, Z. Fabrication of uniform Ag/TiO 2 nanotube array structures with enhanced photoelectron-chemical performance. New J. Chem. 2010, 34, 1335-1340. [CrossRef]

38. Zhu, J.; Zheng, W.; He, B.; Zhang, J.; Anpo, M. Characterization of Fe-TiO 2 photocatalysts synthesized by hydrothermal method and their photocatalytic reactivity for photodegradation of XRG dye diluted in water. J. Hazard. Mater. 2004, 216, 35-43. [CrossRef]

39. Zhou, M.; Yu, J.; Cheng, B. Effects of Fe-doping on the photocatalytic activity of mesoporous $\mathrm{TiO}_{2}$ powders prepared by an ultrasonic method. J. Hazard. Mater. 2006, 137, 1838-1847. [CrossRef] [PubMed]

40. Mishra, T.; Mahato, M.; Noor Aman, J.; Patel, N.; Sahu, R.K. A mesoporous WN co-doped titania nanomaterial with enhanced photocatalytic aqueous nitrate removal activity under visible light. Catal. Sci. Technol. 2011, 1, 609-615. [CrossRef]

41. Markowska-Szczupak, A.; Ulfig, K.; Morawski, A.W. The Application of Titanium Dioxide for Deactivation of Bioparticulates: An Overview. Catal. Today 2011, 169, 249-257. [CrossRef]

42. Serpone, N. Is the band gap of pristine $\mathrm{TiO}(2)$ narrowed by anion- and cation-doping of titanium dioxide in second-generation photocatalysts? J. Phys. Chem. B 2006, 110, 24287-24293. [CrossRef]

43. Sachs, M.; Pastor, E.; Kafizas, A.; Durrant, J.R. Evaluation of Surface State Mediated Charge Recombination in Anatase and Rutile $\mathrm{TiO}_{2}$. J. Phys. Chem. Lett. 2016, 7, 3742-3746. [CrossRef]

44. Schwarz, A.; James, A.; Cristian, I.C.; Karol, P. Dekker Encyclopedia of Nanoscience and Nanotechnology; CRC Press: Boca Raton, FL, USA, 2004; Volume 4. 
45. Zhu, J.; Zhang, J.; Chen, F.; Iino, K.; Anpo, M. High activity TiO 2 Photocatalysts Prepared by a Modified Sol-gel Method: Characterization and their Photocatalytic Activity for the Degradation of XRG and X-GL. Top. Catal. 2005, 35, 261-268. [CrossRef]

46. Kim, K.H.; Ihm, S.K. Heterogeneous catalytic wet air oxidation of refractory organic pollutants in industrial wastewaters: A review. J. Haz. Mat. 2011, 186, 16-34. [CrossRef]

47. Blair, V.L.; Nichols, E.; Liu, J.J.; Misture, S.T. Surface modification of nanosheet oxide photocatalysts. Appl. Surf. Sci. 2013, 268, 410-415. [CrossRef]

48. Chen, Z.Y.; Liang, D.; Ma, G.; Frankel, G.S.; Allen, H.C.; Kelly, R.G. Influence of UV irradiation and ozone on atmospheric corrosion of bare silver. Corros. Eng. Sci. Technol. 2010, 45, 169. [CrossRef]

49. Yadav, P.; Pandey, K.; Bhatt, P.; Tripathi, B.; Kumar, M. Probing the electrochemical properties of $\mathrm{TiO}_{2} /$ graphene $^{2}$ composite by cyclic voltammetry and impedance spectroscopy. Mater. Sci. Eng. B 2016, 206, 22-29. [CrossRef]

50. Bard, A.J.; Faulkner, L.R. Electrochemical Methods; Wiley-Interscience: New York, NY, USA, 1980.

51. Malik, R.; Burch, D.; Bazant, M.; Ceder, G. Particle Size Dependence of the Ionic Diffusivity. Nano Lett. 2010, 10, 4123-4127. [CrossRef] [PubMed]

52. Wang, Y.; Shi, R.; Lin, J.; Zhu, Y. Significant photocatalytic enhancement in methylene blue degradation of $\mathrm{TiO}_{2}$ photocatalysts via graphene-like carbon in situ hybridization. Appl. Catal B Environ. 210, 100, 179-183. [CrossRef]

53. Nguyen-Phan, T.D.; Pham, V.H.; Shin, E.W.; Pham, H.D.; Kim, S.; Chung, J.S.; Kim, E.J.; Hur, S.H. The role of graphene oxide content on the adsorption-enhanced photocatalysis of titanium dioxide/graphene oxide composites. Chem. Eng. J. 2011, 170, 226-232. [CrossRef]

54. Banerjee, A.N. The design, fabrication, and photocatalytic utility of nanostructured semiconductors: Focus on $\mathrm{TiO}_{2}$-based nanostructures. Nanotechnol. Sci. Appl. 2011, 4, 35-65. [CrossRef]

55. Todorova, N.; Vaimakis, T.; Petrakis, D.; Hishita, S.; Boukos, N.; Giannakopoulou, T.; Giannouri, M.; Antiohos, S.; Papageorgiou, D.; Chaniotakis, E.; et al. N and N, S-doped $\mathrm{TiO}_{2}$ photocatalysts and their activity in NOx oxidation. Catal. Today 2013, 209, 41. [CrossRef]

56. Bessegato, G.G.; Cardoso, J.C.; Zanoni, M.V.B. Enhanced photoelectrocatalytic degradation of an acid dye with boron-doped $\mathrm{TiO}_{2}$ nanotube anodes. Catal. Today 2015, 240, 100. [CrossRef]

57. Cavalcante, R.P.; Dantas, R.F.; Bayarri, B.; Gonzalez, O.; Gimenez, J.; Esplugas, S.; Machulek, A. Synthesis and characterization of $\mathrm{B}$-doped $\mathrm{TiO}_{2}$ and their performance for the degradation of metoprolol. Catal. Today 2015, 252, 27-34. [CrossRef]

58. Ranjit, K.; Viswanathan, B. Synthesis, characterization and photocatalytic properties of iron-doped $\mathrm{TiO}_{2}$ catalysts. J. Photochem. Photobiol. A Chem. 1997, 108, 79-84. [CrossRef]

59. Ng, Y.H.; Iwase, A.; Bell, N.J.; Kudo, A.; Amal, R. Semiconductor/reduced graphene oxide nanocomposites derived from photocatalytic reactions. Catal. Today 2011, 164, 353-357. [CrossRef]

60. Lu, L.; Wang, H.; Wenbin, J.; Mkaouar, A.R.; Pei, X. Comparison study on photocatalytic oxidation of pharmaceuticals by $\mathrm{TiO}_{2}-\mathrm{Fe}$ and $\mathrm{TiO}_{2}$-reduced graphene oxide nanocomposites immobilized on optical fibers. J. Haz. Mat. 2017, 333, 162-168.

61. Devaraj, P.; Kumari, P.; Aarti, C.; Renganathan, A. Synthesis and Characterization of Silver Nanoparticles Using Cannonball Leaves and Their Cytotoxic Activity against MCF-7 Cell Line. J. Nanotech. 2013, 2013, 5.

62. Bezrodnaa, T.; Puchkovskaa, G.; Shymanovskaa, V.; Baranb, J.; Ratajczakb, H. IR-analysis of H-bonded $\mathrm{H}_{2} \mathrm{O}$ on the pure $\mathrm{TiO}_{2}$ surface. J. Mol. Struct. 2004, 700, 175-181. [CrossRef]

63. José, O.; Carlos, M.N.R.; Carlos, H.F.; de Renê, S.C.; da Pablo, S.A. Rocha Synthesis, Characterization and

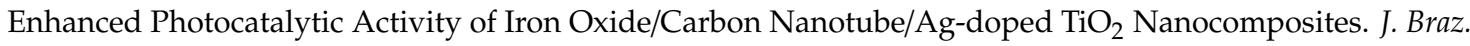
Chem. Soc. 2017, 28, 1678-4790.

64. Reza, K.; Kurny, A.; Gulshan, F. Parameters affecting the photocatalytic degradation of dyes using $\mathrm{TiO}_{2}$ : A review. Appl. Water Sci. 2017, 7, 1569-1578. [CrossRef]

65. Sejie, F.P.; Nadiye-Tabbiruka, M.S. Removal of Methyl Orange (MO) from Water by adsorption onto Modified Local Clay (Kaolinite). Phys. Chem. 2016, 6, 39-48.

66. Niu, P. Photocatalytic Degradation of Methyl Orange in Aqueous $\mathrm{TiO}_{2}$ Suspensions. Asian J. Chem. 2013, 25, 1103-1106. [CrossRef]

67. Milenova, K.; Zaharieva, K.; Stambolova, I.; Blaskov, V.; Eliyas, A.; Dimitrov, L. Photocatalytic performance of $\mathrm{tio}_{2}, \mathrm{CeO}_{2}$, zno and $\mathrm{tio}_{2}-\mathrm{CeO}_{2}$-zno in the course of methyl orange dye degradation. J. Chem. Tech. Met. 2017, $52,13-19$. 
68. Baeissa, E.S. Environmental remediation of aqueous methyl orange dye solution via photocatalytic oxidation using AgeGdFeO 3 nanoparticles. J. Alloys Com. 2016, 678, 267-272. [CrossRef]

69. Wang, Y.; Cheng, H.; Hao, Y.; Ma, J.; Li, W.; Cai, S. Photoelectrochemical properties of metal-ion-doped $\mathrm{TiO}_{2}$ nanocrystalline electrodes. Thin Solid Film. 1999, 349, 120-125. [CrossRef]

70. Archana, P.S.; Jose, R.; Vijila, C.; Ramakrishna, S. Improved Electron Diffusion Coefficient in Electrospun $\mathrm{TiO}_{2}$ Nanowires. J. Phys. Chem. C 2009, 113, 21538-21542. [CrossRef]

71. Zhou, X.T.; Ji, H.B.; Huang, X.J. Photocatalytic Degradation of Methyl Orange over Metalloporphyrins Supported on $\mathrm{TiO}_{2}$ Degussa P25. Molecules 2012, 17, 1149-1158. [CrossRef] [PubMed]

72. Mahmoodi, N.M.; Arami, M.; Limaee, N.Y.; Gharanjig, K.; Ardejani, F.D. Decolorization and mineralization of textile dyes at solution bulk by heterogeneous nanophotocatalysis using immobilized nanoparticles of titanium dioxide. Colloids Surf. A 2006, 290, 125-131. [CrossRef]

73. Banerjee, S.; Pillai, S.C.; Falaras, P.; O'Shea, K.E.; Byrne, J.A.; Dionysiou, D.D. New insights into the mechanism of visible light photocatalysis. J. Phys. Chem. Lett. 2014, 5, 2543-2554. [CrossRef] [PubMed]

74. Prado, A.G.S.; Bolzon, L.B.; Pedroso, C.P.; Moura, A.O.; Costa, L.L. $\mathrm{Nb}_{2} \mathrm{O}_{5}$ as efficient and recyclable photocatalyst for indigo carmine degradation. Appl. Catal. A 2008, 82, 219-224. [CrossRef]

75. Aleksandrzak, M.; Adamski, P.; Kukulka, W.; Zielinska, B.; Mijowska, E. Effect of graphene thickness on photocatalytic activity of $\mathrm{TiO}_{2}$-graphene nanocomposites. Appl. Surf. Sci. 2015, 331, 193-199. [CrossRef]

76. Albiter, E.; Valenzuela, M.A.; Alfaro, S.; Valverde-Aguilar, G.; Martınez-Pallares, F.M. Photocatalytic deposition of $\mathrm{Ag}$ nanoparticles on $\mathrm{TiO}_{2}$ : Metal precursor effect on the structural and photoactivity properties. J. Saudi. Chem. Soc. 2015, 19, 563-573. [CrossRef]

(C) 2019 by the authors. Licensee MDPI, Basel, Switzerland. This article is an open access article distributed under the terms and conditions of the Creative Commons Attribution (CC BY) license (http://creativecommons.org/licenses/by/4.0/). 